\title{
Correction to: Walking the tightrope-perspectives on local politicians' role in implementing a national social care policy on evidence-based practice
}

\author{
A. Bäck ${ }^{1,2^{*}} \oplus$, C. Ståhl ${ }^{3}$, U. von Thiele Schwarz ${ }^{1}$, A. Richter ${ }^{1,2}$ and H. Hasson ${ }^{1,2}$
}

\section{Correction to: Int J Ment Health Syst (2016) 10:75} https://doi.org/10.1186/s13033-016-0107-1

In the original version of this article [1] one of the quotations was unfortunately misattributed. The first quotation "It's more about having an interest in the issues and familiarizing yourself with the working methods and the target group, and so forth. There's no such interest really, but more economic interest" on page 5 should be attributed to manager no 8 , not manager no 20 as stated in the original version.

\section{Reference}

1. Bäck A, Ståhl C, von Thiele Schwarz U, Richter A, Hasson H. Walking the tightrope-perspectives on local politicians' role in implementing a national social care policy on evidence-based practice. Int J Ment Health Syst. 2016;10:75. https://doi.org/10.1186/s13033-016-0107-1.

\section{Publisher's Note}

Springer Nature remains neutral with regard to jurisdictional claims in published maps and institutional affiliations.

\begin{abstract}
Author details
'Department of Learning, Informatics, Management and Ethics, Medical Management Centre, Karolinska Institutet, 17177 Stockholm, Sweden. ${ }^{2}$ Center for Epidemiology and Community Medicine, Stockholm County Council, 171 29 Stockholm, Sweden. ${ }^{3}$ Department of Medical and Health Sciences, National Centre for Work and Rehabilitation, Linköping University, 58183 Linköping, Sweden
\end{abstract}

Published online: 12 May 2021

The original article can be found online at https://doi.org/10.1186/s13033016-0107-1.

*Correspondence: annika.back@ki.se

${ }^{1}$ Department of Learning, Informatics, Management and Ethics, Medical Management Centre, Karolinska Institutet, 17177 Stockholm, Sweden

Full list of author information is available at the end of the article

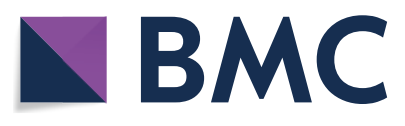

(c) The Author(s) 2021. This article is licensed under a Creative Commons Attribution 4.0 International License, which permits use, sharing, adaptation, distribution and reproduction in any medium or format, as long as you give appropriate credit to the original author(s) and the source, provide a link to the Creative Commons licence, and indicate if changes were made. The images or other third party material in this article are included in the article's Creative Commons licence, unless indicated otherwise in a credit line to the material. If material is not included in the article's Creative Commons licence and your intended use is not permitted by statutory regulation or exceeds the permitted use, you will need to obtain permission directly from the copyright holder. To view a copy of this licence, visit http://creativecommons.org/licenses/by/4.0/. The Creative Commons Public Domain Dedication waiver (http://creativecommons.org/publicdomain/zero/1.0/) applies to the data made available in this article, unless otherwise stated in a credit line to the data. 